\title{
Asertive Training As Character Education To Reduce Smoking Behavior Among Student In Industrial Revolution Era 4.0
}

\author{
Dina Mariana Siregar \\ Mercu Buana Yogyakarta University \\ e-mail: marianadinasiregar@gmail.com
}

\begin{abstract}
Smoking is a form of delinquency at a moderate level, but can provide a tendency for adolescents to lead to more severe delinquency. According to the global youth tobacco survey (gyts) in 2014 the proportion of the age of first attempting to smoke in men aged 10-11 years was 26.7\%, aged $12-13$ years $43.4 \%$, aged $14-15$ years $7.3 \%$. These data address the majority of men who smoke for the first time at the age of 12-13 years. The proportion of women who first tried smoking was 1011 years old $18 \%$, aged $12-13$ years $4 \%$, aged $14-15$ years $21.5 \%$. The occurrence of smoking behavior on the subject is caused by the process of modeling from the social environment, namely by seeing and observing the smoking behavior of his friends then the subject tries to imitate and follow the smoking behavior of his friends psychological intervention indeed to shape the character of students in the era of the industrial revolution 4.0 which is able to reduce smoking behavior in students as a form of preventive measures. Assertive training aims to shape the personality of students so that they are better able to reject the invitation of friends or others to take actions that refer to smoking behavior. This training is expected to be able to change the mindset of students who tend to imitate and copy the behavior of their peers. Assertive training also affects the personality of students who are still lacking the courage to refuse politely and without harming others.
\end{abstract}

\section{Keywords: Character Education, Assertive Training}

Abstract: Merokok adalah bentuk kenakalan pada tingkat sedang, tetapi dapat memberikan kecenderungan bagi remaja untuk mengarah ke kenakalan yang lebih parah. Menurut survei tembakau global (gyts) pada tahun 2014 proporsi usia pertama kali mencoba merokok pada pria berusia 10-11 tahun adalah 26,7\%, usia 12-13 tahun 43,4\%, usia $14-15$ tahun 7,3\%. Data ini membahas mayoritas pria yang merokok untuk pertama kalinya pada usia 12-13 tahun. Proporsi wanita yang pertama kali mencoba merokok berusia 10-11 tahun 18\%, berusia 1213 tahun 4\%, berusia $14-15$ tahun 21,5\%. Terjadinya perilaku merokok pada subjek disebabkan oleh proses pemodelan dari lingkungan sosial, yaitu dengan melihat dan mengamati perilaku merokok teman-temannya maka subjek mencoba meniru dan mengikuti perilaku merokok teman-temannya. karakter siswa di era revolusi industri 4.0 yang mampu mengurangi perilaku merokok pada siswa sebagai bentuk tindakan pencegahan. Pelatihan asertif bertujuan untuk membentuk kepribadian siswa sehingga mereka lebih mampu menolak undangan teman atau orang lain untuk mengambil tindakan yang merujuk pada perilaku merokok. Pelatihan ini diharapkan mampu mengubah pola pikir siswa yang cenderung meniru dan meniru perilaku teman sebaya mereka. Pelatihan asertif juga memengaruhi kepribadian siswa yang masih kurang berani menolak secara sopan dan tidak merugikan orang lain.

Keywords: Character Education, Assertive Training

\section{INTRODUCTION}

Humans are essentially social beings who cannot live alone without the help of others. in the world of education, the formation of character is very necessary for social life, especially in adolescents who are in the transition from childhood to adulthood. This character education will be a reference for students who are adolescent categories to know the

DOI : https://dx.doi.org/10.26486/ijagc.v1i1.1043

URL : http://ejurnal.mercubuana-yogya.ac.id/index.php/IJAGC/index

Email: ijagc@mercubuana-yogya.ac.id 
limits in attitude and make choices so that no harmful actions occur that lead to the destruction of moral values and can interfere with the task of developing adolescents as the nation's successors

Early adolescence is a transition period, where the age ranges from 13 to 16 or 17 years and the end of adolescence from 16 or 17 years to 18 years, namely legal ripe age (Hurlock, 2002). The end of adolescence is a very short period. At this age limit, adolescents must make some adjustments, including achieving maturity with independence, selfconfidence and ability to face life, achieving positions accepted by society, responsibilities, morality, and values that are appropriate to the environment and culture, solving real problems in their own experience and in relation to the environment (Sarwono, 2004). The psychological aspect is one of the factors that play an important role in the emergence of smoking behavior in adolescents which will eventually become a habit and an addiction to smoking. It can be ascertained that each individual is different so that the reasons or factors that cause the emergence of smoking behavior also differ in each teenager. Smoking must be stopped immediately, one of which can be done with the prevention of smoking behavior that starts with adolescents. This cessation becomes quite difficult because Indonesia has not been much basic research on the factors that influence smoking behavior and what is the most dominant factor, especially in adolescents, namely the age at which someone starts smoking (Wulan, 2012)

Smoking is a form of delinquency at a moderate level but can provide a tendency for adolescents to lead to more severe delinquency (Masngudin, 2014). Smoking behavior is classified as behavior that can endanger health, both for smokers and for others around them. Smoking is proven to be associated with 25 types of dangerous diseases that are deadly, including lung cancer and coronary heart disease. Every year, the number of deaths due to smoking increases, but the number of smokers also increases, even the age of someone smoking is also getting younger. Teenagers reach a high number as a person's early age smoking. The motivation of adolescents to smoke is generally due to psycho-social factors, among others because they join in, imitating parents and siblings, imitating peers, wanting to be called an adult, trial, and error (Astoni, 1999).

For adolescents, smoking is a passport to get a popular identity, follow trends/fashion and a "difficult" identity (Lucas \& Lloyd, 2005). In the early 20th century, before a teenage boy was considered an adult he was demanded to smoke, since then smoking finally became the road to be passed before a young man was accepted as an adult. In everyday life, culture like this arises in the form of mentioning "sissy" for teenage boys who don't smoke. This clearly suppresses adolescents who don't smoke psychologically, eventually they become melted and smoked. Whereas in adolescent women one of the reasons for smoking is to maintain ideal body weight.

Smoking must be stopped immediately, one of which can be done with the prevention of smoking behavior that can be started at the age of adolescence so that adolescents can complete developmental tasks as they should. From the various effects of smoking behavior that have been described above, it can be concluded that smoking behavior has a negative impact on various aspects of human life such as health (cancer, lung, heart, hypertension), the community economy (smokers spend more money to buy cigarettes rather than meeting their basic daily needs and as a result of smoking makes sick so that it reduces work productivity), social environment (can cause death for passive smokers inhaling cigarette smoke that contains lots of chemical compounds) (Ramopoly, 2015)

Smoking behavior is a behavior that involves the process of burning tobacco which is then inhaled, using cigarettes or pipes (Sitepoe, 2000). It turns out smoking behavior is not only found in adults but also can be found in adolescents. Smoking behavior in adolescents generally will increasingly increase in accordance with the stage of its development which is 
characterized by increased frequency and intensity of smoking (Hasnida \& Kemala, 2008). (Smet, 1994) said that the age of first smoking generally ranged between 11-13 years. Smoking behavior will be measured by four aspects of (Aritonang, 1997) namely smoking function, smoking intensity, smoking area, and smoking time.

According to the national commission on child protection in 2012 the age of smokers in Indonesia is now getting younger and has even touched the age of children. This condition causes Indonesia to be called a baby smoker country or child smoker. The number of smokers of children aged 10-15 years in Indonesia between 2008 and 2012 amounted to 1,200,000, and children aged less than 10 were 239,000. The number of smokers in Indonesia based on the age trend of smoking 10-15 years in 2007 the percentage was 9.6\%, 2010 amounted to $17.5 \%$, and 2013 rose to $18 \%$. The proportion of the average number of cigarettes consumed by men with 1 stick per day was $35.6 \%$, consumption of $2-5$ cigarettes per day was $23.1 \%$, consumption of 6-10 cigarettes per day was $5.9 \%$. While the proportion of the average number of cigarettes consumed by women with 1 cigarette per day was 31.5\%, 2-5 cigarettes per day were $10.2 \%$ (MOH RI, 2013).

One factor that makes teens become smokers is high intimacy. (Berdnt \& Perry, 1986) state that one of the characteristics of adolescent friendship is intimacy, where adolescents seek psychological closeness, trust, and mutual understanding. This intimacy makes teens become smokers because teenagers try to understand their friends who smoke. One of them by not behaving assertively, namely reprimanding his friend who smoked.

(Salim, 1995) suggests that adolescents who have a high tendency to smoke will allow themselves to smoke. This is what will not be in accordance with the tasks and development of adolescents as students who need to be more active and productive, namely learning and making works that are useful in the academic and non-academic fields.

The existence of these problems, we need a form of psychological intervention that can reduce smoking behavior in early adolescence as a form of preventive measures. The formation of adolescent behaviors that are more productive and active in developing their potential both in academics, emotional control, and social relationships can be obtained by providing training in behavioral skills. Training is a form of psychological intervention that can provide learning for trainees to improve their abilities, knowledge, skills, and attitudes that are better aligned with the objectives set in the training.

One of the trainings for teenagers to be more assertive in rejecting invitations is Assertive Training. Assertive training is an interpersonal behavior that involves aspects of honesty and openness of mind and feelings that are characterized by the ability to adapt to the environment. Assertive behavior is behavior that shows self-confidence and respect for oneself and others (Jones \& Nelson, 2011).

Assertive training is one of the techniques in behavioral counseling that can shape a person's character. Where the nature of counseling according to behavioral is the process of providing assistance in learning group situations to solve problems interpersonal, emotional, and make decisions in controlling their own lives and learn new behaviors accordingly. The purpose of this assertive exercise is for someone to learn how to replace responses that do not correspond to new responses that are appropriate.

Assertive training aims to shape the personality and character of students so that they are better able to reject the invitation of friends or others to take actions that refer to smoking behavior. This training is expected to be able to change the mindset of students who tend to imitate and copy the behavior of their peers. Assertive training also affects the personality of students who are still lacking the courage to refuse politely and without harming others. Inability to reject the invitation because it will be opposed by members of the group, offending friends in the group, not considered as members of the group, and so on. This has a negative impact not only on students but also on schools and parents. By smoking they will 
experience health problems, an allowance is used up because they are used to buy cigarettes, and performance decreases because they often leave the lesson just to smoke, crossing out the good name of the school and embarrassing parents.

Basically rejecting the invitation of others is the right of everyone if the invitation is not in accordance with him, of course, how to reject the invitation is done properly and correctly so that it does not hurt and offend others. Based on the literature review in guidance and counseling there are strategies that can be used to help students communicate what they want, in this case rejecting the invitation of friends to smoke, namely by using assertive exercises. At present Indonesia is entering the era of industrial revolution 4.0 which has great potential benefits but also has great challenges if it is not wise to face. With this all-round and sophisticated era, people are increasingly spoiled by technology, people are increasingly thinking instantly, so human characters are running low. So that the industrial era 4.0 becomes a disruption/problem of people who are not wise in dealing with this era. With easy access to technology/internet, don't make students increase their juvenile delinquency rates because imitation and conformity can also occur through technology, for example, to get recognition from adolescent peer groups will post photos of familiarity on social media and will usually exhibit smoking behavior so that looks cool and feels mature.

Based on the description of the background of the problem that has been explained above, the researcher wants to see how influential assertive training has been on reducing the intensity of smoking behavior in early adolescent students in the industrial revolution era 4.0.

\section{METHODS}

This research was conducted by analyzing the results of previous research related to smoking behavior factors, then discussed using cognitive behavioral theory. The previous studies that have been found by the author are as follows:

Table 1 Prior Research

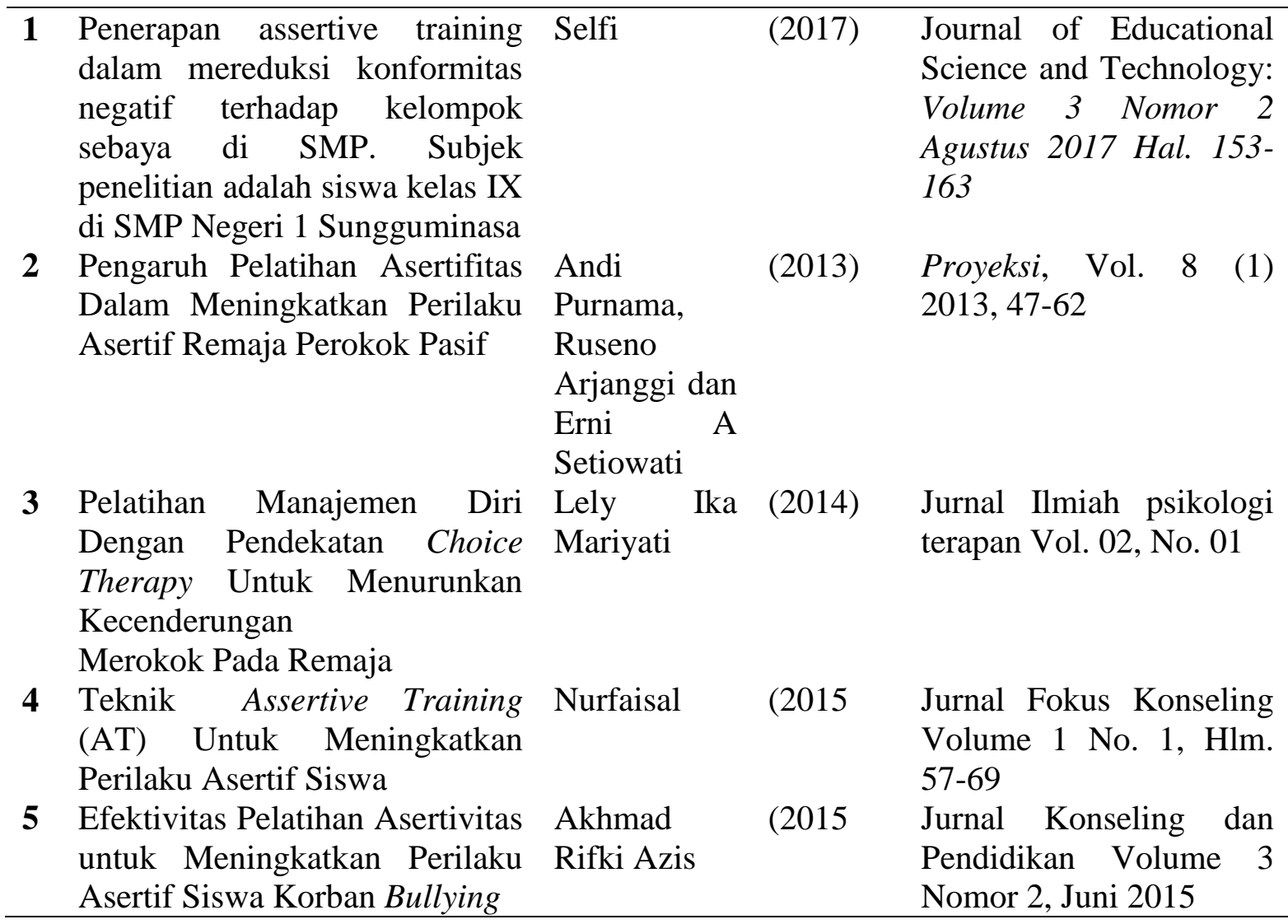




\section{FINDINGS AND DISCUSSION}

Based on the results of a review of five articles in the last 10 years found the factors of assertive behavior that led to the emergence of smoking behavior of high school students as follows:

Table 2 Analysis Results

1 Based on the assertiveness level table, it shows that the level of negative conformity of students in Junior High School 1 Sungguminasa, before being given assertive training techniques is in the very high category of 2 respondents $(18.18 \%)$, and high as many as 9 respondents $(81.82 \%)$. However, after being given treatment in the form of assertive training techniques for 6 stages, the level of negative conformity of students showed positive changes, meaning a significant decrease, where the high category was 1 respondent $(9.09 \%)$, the low category was 8 respondents $(72.73 \%)$, and very low categories of 2 respondents $(18.18 \%)$. Thus, it can be concluded that the application of assertive training techniques can reduce negative conformity to peer groups in Junior High School 1 Sungguminasa.

2 Hypothesis testing is done by a nonparametric statistical analysis technique, namely Wilcoxon signed test. Hypothesis test results show $\mathrm{Z}=-0.470$ and significance $(\mathrm{p})$ of $=0.638$ so that it can be interpreted that there is no significant difference between passive smoker's assertive behavior scores before and after given assertiveness training.

3 The analysis showed that $(F=6.287 ; \rho=0.02 ; \rho<0.05 ; \eta=0.215)$, while in the anacova test for follow-up data $(F=7,223 ; \rho=0.013 ; \rho<0.05 ; \eta=0,239)$, this shows that there is a difference in the tendency of smoking behavior that gets the treatment of self-management training with the choice theory approach with the non-treatment of self-management training with the choice theory approach by controlling the tendency of smoking behavior before treatment.

4 The profile of student assertiveness of Senior High School Kartika Siliwangi 2 Bandung at grade 10, academic year 2012/2013 found that student assertiveness at low category. low category meant that student don't have much skill for being assertive. intervention program such as assertive training are effective to raise student assertiveness becoming better.

5 In accordance with the purpose of the study is to determine the effectiveness of assertiveness training to improve the assertive behavior of students who are victims of bullying. This can be seen from the results of the posttest which shows the significance between the experimental group and the control group is 0.020 . Based on the above statement, it can be concluded that after attending assertiveness training, bullying students are able to be assertive in dealing with their problems; students acquire the skills to express negative feelings, self-affirmation and express positive feelings.

According to (Sitepoe, 2000) smoking behavior is a behavior that involves the process of burning tobacco which is then inhaled, using cigarettes or pipes. Nowadays, smoking is a common behavior, smokers come from various social classes and different age groups. This might be caused by smoking easily and can be obtained wherever and whenever. Smoking is a category of juvenile delinquency at a moderate stage but can give a tendency for adolescents to aim at more severe delinquency.

To reduce smoking behavior in students, intervention is needed, one of which is assertive training. Basically, behavioral therapy is directed at the goals of obtaining new behavior, eliminating maladaptive behavior, and strengthening and maintaining desirable 
behavior. Assertive training is training that can be applied especially in interpersonal situations where individuals have difficulty accepting the fact that expressing or asserting themselves is an appropriate or correct action. (Alberti \& Emmons, 2002) mentions aspects of assertiveness as follows:

a. Act according to their own wishes

Includes the ability to make decisions, take initiative, believe in oneself, can set a goal and try to achieve it, and be able to participate in the association.

b. Able to express feelings of honesty and comfort

Includes the ability to express disapproval, anger, show affection and friendship with others and acknowledge feelings of fear or anxiety, express approval, show support, and be spontaneous.

c. Cable to defend themselves

Includes the ability to say "no" when needed, able to respond to criticism, reproach, and anger from others, openly and able to express and defend opinions.

d. Able to express opinions

Includes the ability to express opinions or ideas, make a change, and respond to violations against themselves and others.

e. Not ignore the rights of others

It includes the ability to express criticism fairly without threatening, manipulating, intimidating, controlling, and hurting others.

(Alberti \& Emmons, 2002) add that there are several components in assertiveness. These components are:

a. Eye contact (eye contact)

A speaking person who is assertive shows eye contact by looking directly at the other person so that it will help in communicating sincerity, showing concern and respect for others and increasing the continuity of the message conveyed.

b. Body attitude (body posture)

The posture of the assertive individual is an active and upright posture. A bent and passive stance indicates a lack of assertiveness.

c. Distance or physical contact (distance or physical contact)

Assertive individuals have the ability to keep their distance when interacting with others. The closeness between people involved in the conversation will have a considerable impact on communication. However, if it is too close it might be able to offend others.

d. Gesture

The cues shown by assertive individuals can add to the assertiveness, openness, warmth, self-confidence and spontaneity in communicating with others.

e. Facial expressions (facial expression)

In talking with others, assertive individuals are able to express faces in accordance with the message or what will be conveyed.

f. Tone, modulation, volume

When expressing thoughts and feelings verbally, assertive individuals use the right intonation

g. Timing

Assertive individuals are able to express things to others appropriately according to time and place.

h. Listen

Assertive individuals have the ability to listen carefully when the other person is talking, so they are able to refrain from expressing themselves for a moment.

i. Fill (content)

Assertive individuals are able to express their thoughts and feelings by choosing the right 
sentence in communicating with other people.

\section{CONCLUSION}

1. From the description above, it can be concluded that assertive training is one part of cognitive behavior theory where assertive training is an interpersonal behavior that involves aspects of honesty and openness of mind and feelings that are characterized by the ability to adapt to the environment.

2. Based on the description above, it can be concluded that smoking behavior is an activity or activity to burn cigarettes and then inhale it and exhale it out and can cause smoke that can be sucked by people around him.

It is hoped that the next researcher will develop the results of this discussion with a deeper study of each factor and make an intervention in reducing student smoking behavior.

\section{REFERENCES}

Azis, AR. (2015). Efektivitas Pelatihan Asertivitas untuk Meningkatkan Perilaku Asertif Siswa Korban Bullying. Jurnal Konseling dan Pendidikan, 3(2),

Alberti, R., \& Emmons, M. (2002). Your perfect right "hidup lebih bahagia dengan menggunakan hak”. Jakarta: PT. Elek media komputindo, ed.

Aritonang, M. (1997). Fenomena wanita merokok. Skripsi. Yogyakarta: Universitas Gadjah Mada Press.

Astoni, M.A.M.Z. (1999). Pengetahuan, Sikap dan Perilaku Merokok serta Prevalensi perokok pada remaja di kelurahan Marianan Kecamatan Banyuasin I Kabupaten Musi Banyuasin. Jurnal Kedokteran Universitas Sriwijaya.

Berdnt, TJ., \& Perry, TB. (1986). Children's perseption of friendships as supportive relationships. Development Psychologi, 22.

Depkes RI. (2013). Riset kesehatan dasar (Badan Penelitian dan pengembangan Kesehatan Kementrian Kesehatan RI, ed.). Jakarta.

Hasnida \& kemala, I. (2008). Hubungan antara stres dan perilaku merokok pada remaja lakilaki. Jurnal Psikologi, 1(2), 92-97.

Hurlock, E. (2002). Psikologi perkembangan (Erlangga, ed.). Jakarta.

Jones, \& Nelson, R. (2011). Teori dan praktik konseling dan terapi. Yogyakarta: Pustaka pelajar, ed.

Mariyati, LI. (2014). Pelatihan manajemen diri dengan pendekatan choice therapy untuk menurunkan kecenderungan merokok pada remaja. Jurnal Ilmiah Psikologi Terapan, 2(1),

Lucas, K., \& Lloyd, B. (2005). Health promotion evidence and experience. London: SAGE Publications.

Masngudin. (2014). Kenakalan remaja sebagai perilaku menyimpang hubungannya dengan keberfungsian sosial keluarga. Laporan Penelitian. 
Nurfaisal. (2015). Teknik assertive training (AT) untuk meningkatkan perilaku asertif siswa. Jurnal Fokus Konseling, 1(1), 57-69

Purnama, A., Arjanggi, R., \& Setiowati, EA. (2013). Pengaruh pelatihan asertifitas dalam meningkatkan perilaku asertif remaja perokok pasif. Proyeksi, 8(1), 47-62.

Ramopoly. (2015). Latihan kontrol diri untuk penurunan perilaku merokok pada perokok ringan. Jurnal Psikologi, 17(2).

Salim, A. (1995). Perubahan sosial, sketsa teori dan refleksi metodoloogi kasus Indonesia. Yogyakarta: Tiara Wacana.

Selfi. (2017). Penerapan assertive training dalam mereduksi konformitas negatif terhadap kelompok sebaya di SMP. Journal of Educational Science and Technology, 3(2), 153163.

Sarwono, S. (2004). Pisikologi remaja (8th ed.). Jakarta: Raja Gafindo Pustaka.

Sitepoe. (2000). Kekhususan rokok indonesia. Jakarta: PT. Gramedia widiasrana.

Smet. (1994). Psikolodi kesehatan (P. G. widiasarna Indonesia, ed.). Jakarta.

Wulan, D. K. (2012). Faktor Psikologis yang Mempengaruhi Perilaku Merokok pada Remaja. Humaniora, 3(2), 504. 